\title{
İç Mekânlarda Öz Lateration'nın Performansının Değişen Erişim Noktası Sayısına ve İterasyonlara Bağlı Olarak İncelenmesi
}

\author{
Korhan Cengiz ${ }^{*}$ \\ ${ }^{1}$ Trakya Üniversitesi, Mühendislik Fakültesi, Elektrik-Elektronik Mühendisliği Bölümü, Edirne, Türkiye (ORCID: 0000-0001-6594-8861)
}

(Bu yayın 26-27 Haziran 2020 tarihinde HORA-2020 kongresinde sözlü olarak sunulmuştur.)

(DOI: 10.31590 /ejosat.779511)

ATIF/REFERENCE: Cengiz, K. (2018). Investigating the Performance of Pure Lateration in Indoor Environments Based On Varying Number of Access Points and Iterations. European Journal of Science and Technology, (Special Issue), 130-134.

$\ddot{\mathbf{O} z}$

Günümüzde, kullanıcıların ve aygıtların iç mekanlarda konumlarının belirlenmesi gelecek vaat eden bir araştırma konusudur. İ̧̧ mekanlar için kullanıcıların konumlarının doğru olarak belirlenmesi halk güvenliği, süper marketler, sağlık hizmetleri uygulamaları, seyahat, sosyal ağlar ve turizm gibi birçok uygulamada kullanılmaktadır. Fakat, dış mekanlar için tasarlanmış küresel konumlandırma sistemleri iç mekan konumlandırma sistemleri için kullanılamaz çünkü iç mekan konumlandırması için hedefin kesin pozisyonunun kestirilmesi bir problemdir. İç mekanlar için, lateration, fingerprinting dead reckoning gibi çeşitli konumlandırma algoritmaları bulunmaktadır. Lateration mevcut algoritmalarla karşılaştırıldığında düşük fiyatlı ve kolay uygulanabilirdir. Bu yüzden, bu çalışmada, MATLAB dan üretilmiş sentetik veri kullanan alınan sinyal gücü easlı saf lateration önerilmektedir. Lateration'nın performansı değişen erişim noktası sayısının etkisi, değişken Gauss gürültüsü ve iterasyona bağlı değişim gibi çeşitli performans metrikleri açısından incelenmiştir. Saf lateration' nın benzetimleri MATLAB' da yapılmıştır. Performans metriklerinin etkisi detaylı bir şekilde incelenmiş ve tartışılmıştır. Sonuçlara göre, alandaki erişim noktalarının sayısı arttı̆̆ında, Lateration'nın doğruluk performansı artmaktadır fakat bu bazı donanım maliyetleri getirecektir. Beklendiği gibi, alandaki Gauss gürültüsü arttığında, laterationın hata performansı kötüleşmektedir. Bu çalışmanın esas amacı, lateration için gerçek zaman uygulamalarına bir çözüm sağlayacak optimum koşulların elde edilmesidir. Gelecek çalışmalar olarak, bu çalışmanın gerçek zaman uygulamaları gerçekleştirilecektir ve doğruluk performansını arttırmak için ölçülen değerlere eğri uydurma fikrinin uygulanması amaçlanmaktadır.

Anahtar Kelimeler: Öz Lateration, İç Mekân Konumlandırma, Üçgenleme, GPS.

\section{Investigating the Performance of Pure Lateration in Indoor Environments Based On Varying Number of Access Points and Iterations}

\begin{abstract}
Nowadays, determining the location of the users and devices in indoor buildings is promising research topic. Accurate position determination of the users for indoor environments is used for numerous applications such as public safety, supermarkets, health care applications, travelling, social networks and tourism. However, global positioning systems created for outdoor localizations cannot be used for indoor positioning systems (IPS) because detecting the exact position of a target is an issue for IPS. For indoor environments, there are several positioning algorithms such as lateration, fingerprinting, dead reckoning etc. Lateration is low cost and easy to deploy when compared to other existing algorithms. Therefore, in this study, received signal strength based pure lateration that uses synthetic data generated from MATLAB is proposed. The performance of pure lateration is investigated in terms of several performance metrics such as effect of varying number of the access points (AP), varying Gaussian Noise power and variations based on iterations. The simulation of the pure lateration algorithm is conducted in MATLAB. The effect of the performance metrics is investigated and discussed in details. According to the results, accuracy performance of lateration is increased when the number of APs increase in the area, however this will bring some hardware costs. As expected, when the Gaussian Noise increases in the area,
\end{abstract}

* Sorumlu Yazar: Trakya Üniversitesi, Mühendislik Fakültesi, Elektrik-Elektronik Mühendisliği Bölümü, Edirne, Türkiye, ORCID: 0000-0001-65948861, korhancengiz@trakya.edu.tr 
the error performance of pure lateration becomes worse. The main purpose of this study is to obtain the optimum conditions for lateration to provide a solution for real time applications. For future work, the real time implementations of this study are performed and to improve the accuracy performance, it is aimed to use a curve fitting idea to the measured values.

Keywords: Pure lateration, Indoor Positioning, Triangulation, GPS.

\section{Introduction}

Determining a device's location has become a significant requirement in various applications in recent years. In 1995 Global Positioning System (GPS) became completely useful. The GPS is a space-based satellite navigation system that provides information about location and time under all situations, anywhere there is an unimpeded line of sight of three or more GPS satellites [1]. The GPS provides a method for triangulation to track the users' physical locations in outdoor environments. At the other hand, it is not useful for accurately determining the user positions in indoor environments [2]. The concrete walls cause the signals received from satellites to attenuate, and thus the signals do not reach the walls. Therefore, finding a target position in a building becomes unfeasible.

In recent years, thanks to the improvements in the technologies, people spend their days in indoor places thus the demand for indoor positioning techniques increases. People can use IPS in indoor buildings such as an arrival gate in an airport, hospital patient services, or supermarket. A variety of applications for indoor spaces can be realized with prosperous IPS updates [3]. To illustrate, IPS can be used to perform security, social networks, and health care applications. Furthermore, as for example, indoor localization technique can also ensure innovative and accurate ways to find out a person's position in a building in the event of a disaster.

Recently, with the above-mentioned improvements, IPS has become a popular research topic, so many researches and studies have been implemented in the field of IPS. The authors propose several IPS studies [5]. In a Received Signal Strength (RSS)-based localization systems [6], the location of an user can be determined by computing the distance of a target from the transmitter utilizing triangulation or lateration scemes.

The well-known methods used for signal measurements are: Angle of Arrival (AOA), Time of Arrival (TOA), Time Difference of Arrival (TDOA) and Received Signal Strength Indicator (RSSI) [3]. AOA [7] requires to measure the angles at which the signal arrives to the anchor nodes from the unlocated device. This algoritm needs only two units of measurement for 2D-localization and does not require synchronizations between the units. AOA can be used ably when LOS exists but in multi-path environments, the accuracy decreases. TOA uses the distances between the transmitters and the receivers from the delays in transmission time and the corresponding signal speed to determine the object positions $[8,9]$. TOA ensures high accuracy, but, it causes to extra costs due to the high hard-ware complexity. In addition, TDOA technique utilizes distance-based measurements to assess object positions [10]. They find the transmitter relative positions based on the TOA variations in the transmitting node and multi-sensor propagation of the signals. The difference in arrival time can be utilized when the signal arrives two reference points to measure the variations in distances between the object and the two reference points. It is less complicated than TOA, and provides remarkable performances of accuracy.

An RSSI value is the indicator of the RSS strength level. It is calculated by a negative number corresponding to the decibelmilliwatt $(\mathrm{dBm})$. If the received signal is powerful, the value gets closer to zero. To determine the position of a device with RSSI, the RSSI values between the sensors attached to a target and ambient access points (APs) with default locations should be measured [11]. The combinations of these multiple RSSI values can be used to determine the approximate position of the target. Generally, at least 3 APs are required to determine an object 's position. The locations of the users are attained by using tri-angulation or trilateration schemes to calculate object distances from sender nodes. RSSI-based positioning is simple to perform as compared with the AOA and TDOA techniques [12]. For RSSI techniques, there is no need to use specific equipments on both mobile phones and wireless interface cards [13].

\section{Pure Lateration Technique}

Location detection by the help of distance measurements using signal strengths is named as lateration [17]. This scheme is used in IPS due to its preciseness and cheapness. The lateration techniques are based on position information of the reference points and the distances to them.

Firstly, to find the accuracy error of pure lateration, the RSSI Matrix which includes noisy RSSI measurements of APs on each test point in a room can be defined as shown below:

$X_{R S S I}=\left[\begin{array}{ccc}\operatorname{RSSI}_{(1,1)} & \cdots & \operatorname{RSSI}_{(1, T)} \\ \vdots & \ddots & \vdots \\ \operatorname{RSS}_{(K, 1)} & \cdots & \operatorname{RSSI}_{(K, T)}\end{array}\right]$

Here, $\mathrm{T}$ corresponds to number of test points in the measurement area and $\mathrm{N}$ denotes the number of APs in the field. As instance, $\mathrm{T}$ can be 196 and $\mathrm{K}$ can be 4 . The distance of an object from the transmitter can be computed by using (2) given below, after measuring the received power at the target position given that $\mathrm{A}$ and $\mathrm{n}$ values are known: 
$r_{P}=10^{\frac{A-X_{R S S I}(x, y)}{10 n}}$

In here, $A$ value shows the power of an $\mathrm{AP}$ in $\mathrm{dBm}$ and $\mathrm{n}$ corresponds to the path loss exponent of the environment. By using $\mathrm{r}_{\mathrm{P}}$ values and following two equations, Eq. (5) can be obtained:

$C_{a c t}=\left[\begin{array}{cc}2\left(x_{2}-x_{1}\right) & 2\left(y_{2}-y_{1}\right) \\ \vdots & \vdots \\ 2\left(x_{K}-x_{1}\right) & 2\left(y_{K}-x_{1}\right)\end{array}\right]$

$D=\left[\begin{array}{c}r_{p 1}^{2}-r_{p 2}^{2}+x_{2}^{2}+y_{2}^{2}-x_{1}^{2}-y_{1}^{2} \\ \vdots \\ r_{p 1}^{2}-r_{K}^{2}+x_{K}^{2}+y_{K}^{2}-x_{1}^{2}-y_{1}^{2}\end{array}\right]$

$\left[\begin{array}{l}x_{\text {est }} \\ y_{\text {est }}\end{array}\right]=\left(C_{a c t}^{T} C\right)^{-1} C_{a c t}^{T} D$

Eq. (5) shows the estimated locations of the pure lateration method. To find the estimated error in each test point, the difference between estimated locations and actual locations can be used as shown in (6):

$e=\left[\begin{array}{l}x_{e s t} \\ y_{\text {est }}\end{array}\right]-\left[\begin{array}{l}x \\ y\end{array}\right]$

\section{Simulation Results of Lateration}

Simulations and analyses of pure lateration are conducted in MATLAB. The results of simulations and discussions are presented in this section. Varying number of access points (APs), varying step sizes and Gaussian Noise parameters are used to obtain several simulation results.

Fig. 1 illustrates the error value of each test point of pure lateration under low Gaussian Noise (standart deviation of noise is 2). Here, there are 196 test points and 4 APs which are located at the corners of measurement field. The dimensions of the field are $6 \mathrm{~m} x$ $6 \mathrm{~m}$. From this figure, it is obtained that lateration error increases especially when the test points are very close to the APs. The whole distribution of the lateration error on each point can be obtained from this figure. Note that, in here the average lateration error is approximately $1.3321 \mathrm{~m}$.

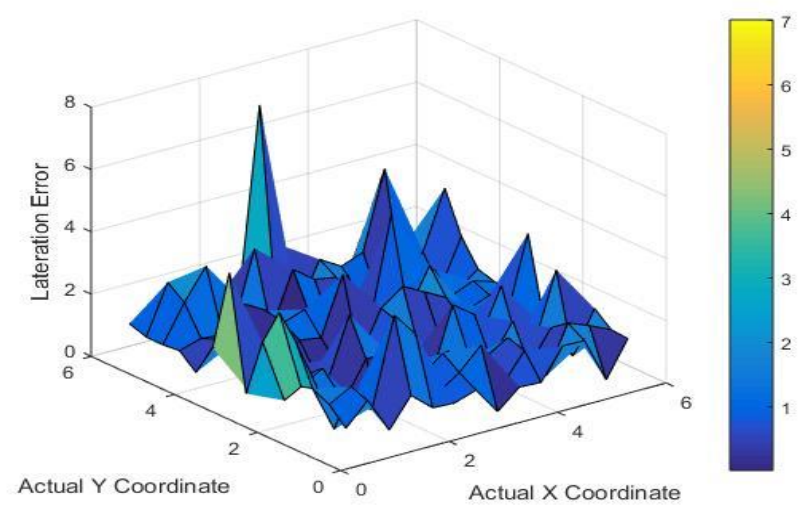

Figure 1. Lateration error distribution of each point under low Gaussian Noise

Fig. 2 illustrates the error distribution of each test point of pure lateration under lower Gaussian Noise (standart deviation of noise is 1). Here, there are 196 test points and 4 access points which are located at the corners of measurement field. The dimensions of the field are $6 \mathrm{~m} \times 6 \mathrm{~m}$. From the figure, it is obtained that lateration error increases especially when the test points are very close to the 
APs. The whole distribution of the lateration error on each point can be obtained from this figure. Note that, in here the average lateration error is approximately $0.5869 \mathrm{~m}$. The average error is decreased dramatically when the noise is decreased.

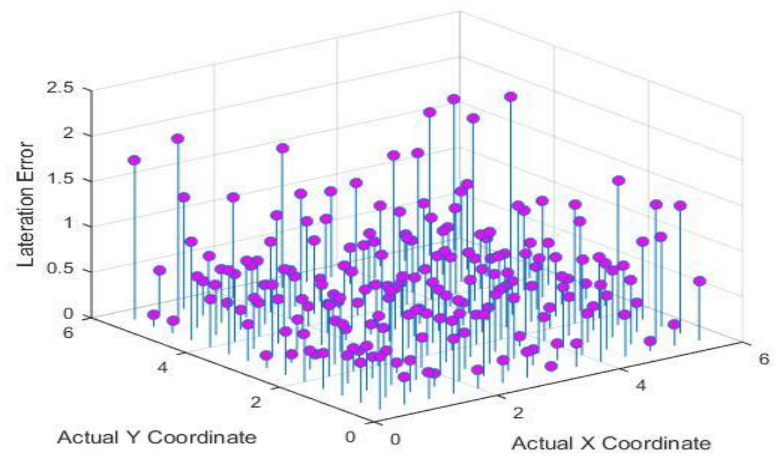

Figure 2. Lateration error distribution of each point under lower Gaussian Noise

To investigate the effect of Gaussian Noise on pure lateration, the simulations are conducted for varying Gaussian Noise values. Fig. 3 shows the average error performance of pure lateration in term of varying Gaussian Noise. The average error increases when the noise increases in the system as expected.

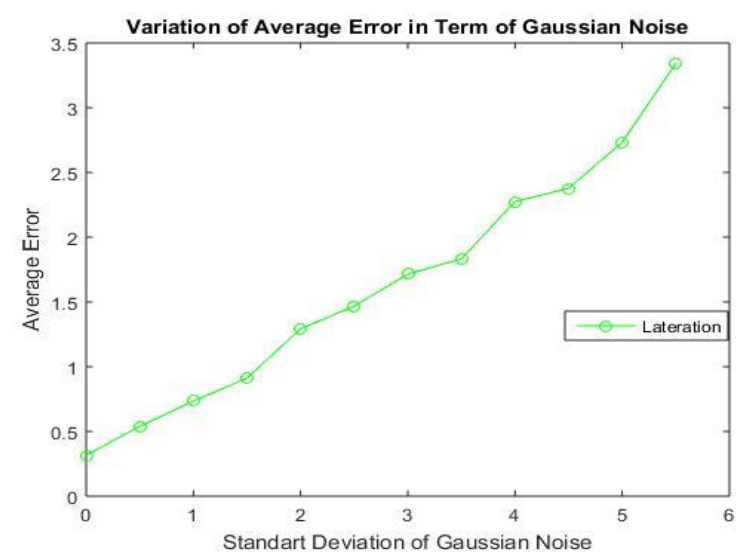

Figure 3. Average lateration error according to different noise values

Fig. 4 shows the actual and the estimated positions of the users under lower Gaussian Noise (standart deviation of 1). From this figure, it is obtained that lateration is successful indoor positioning algorithm for detecting the actual locations of the users in indoor environments.

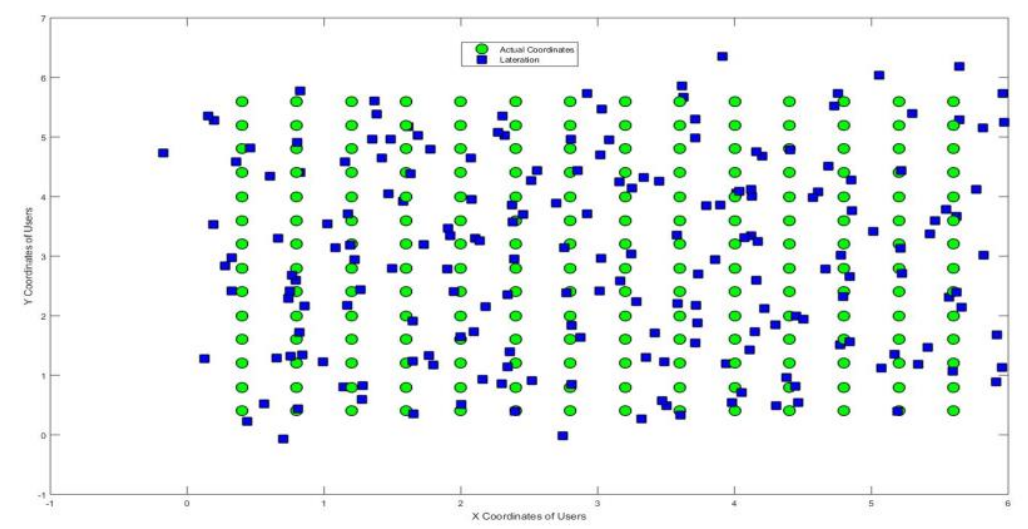

Figure 4. Actual and Estimated Locations of the Users

Table 1 shows the variation of lateration error according to varying number of APs under 100 independent iterations. Here, there are 196 test points and noise parameter is 2 in $6 \mathrm{~m} \mathrm{x} \mathrm{6m} \mathrm{field.} \mathrm{According} \mathrm{to} \mathrm{these} \mathrm{simulation} \mathrm{results,} \mathrm{it} \mathrm{is} \mathrm{obtained} \mathrm{that,} \mathrm{when} \mathrm{the}$ number of APs increase in the measurement area, the error performance of pure lateration enhances. However, increasing the number of APs brings extra computational, hardware and financial costs to the designers and researchers. 
Table 1. Average Lateration Errors According to Different Number of APS

\begin{tabular}{|c|c|}
\hline Number of APs & Average Lateration Error in meters \\
\hline 3 & 1.6925 \\
\hline 4 & 1.3182 \\
\hline 6 & 1.2301 \\
\hline 8 & 1.1324 \\
\hline
\end{tabular}

Table 2 shows the error performance of pure lateration for the parameters: 4 APs and 196 TPs under 100 independent iterations. As expected and discussed above, when the noise increases in the measurement environment, the accuracy performance of pure lateration decreases dramatically.

Table 2. Average Lateration Errors According to Varying Gaussian Noise

\begin{tabular}{|c|c|}
\hline Standart Deviation & Average Lateration Error in meters \\
\hline 0.05 & 0.0304 \\
\hline 0.2 & 0.1227 \\
\hline 0.5 & 0.3062 \\
\hline 1 & 0.6205 \\
\hline 2 & 1.3229 \\
\hline 4 & 3.3409 \\
\hline 5 & 4.9849 \\
\hline
\end{tabular}

\section{Conclusion}

Detecting the locations of the users in buildings has been an important research topic recent years. IPS can be utilized a variety of fields such as, shopping applications, social platforms, logistics, tourism sectors and transportation. However, GPS is designed for outdoor places, is not proper for IPS, making certain location determination a extorsive issue for IPS. In this study, pure lateration method that uses existing infrastructure, is proposed. By increasing the number of APs, the pure lateration technique improves the precision of location estimations. The usage of the existing substructure turns the designed method into cheaper when comparing with existing solutions that need pricy components. The proposed method is investigated under different performance metrics in MATLAB. The results of the simulations are evaluated and discussed in details to determine the optimum solution of pure lateration in indoor environments. As a future work, it is planned to use polynomial fitting algorithms to enhance the accuracies of the lateration schemes.

\section{References}

[1] H. Koyuncu and S. Yang, "A Survey of Indoor Positioning and Object Locating Systems," IJCSNS International Journal of Computer Science and Network Security, vol. 10, no. 5, pp.121-128, 2010.

[2] S. Gezici, "A survey on wireless position estimation," Wireless Personal Communications, vol. 44, pp. 263-282, 2008.

[3] W. Sakpere, O. Adeyeye, N. Mlitwa, "A State-of-the-Art Survey of Indoor Positioning and Navigation Systems and Technologies”, South African Computer Journal, no. 2, vol. 3, pp. 145-197, 2017.

[4] A. Yassin et al., "Recent Advances in Indoor Localization: A Survey on Theoretical Approaches and Applications", IEEE Communications Surveys \& Tutorials, vol. 19 no. 2, pp.1327-1346, 2017.

[5] D. Zhang et al., "Localization Technologies for Indoor Human Tracking", in Proc. of 5th International Conference on Future Information Technology, 2010.

[6] T. Mounir et al., "Positioning system for emergency situation based on RSSI measurements for WSN", in Proc. of International Conference on Performance Evaluation and Modeling in Wired and Wireless Networks (PEMWN), 2017.

[7] Y. Lee, "Weighted-average based aoa parameter estimations for LR-UWB wireless positioning system", IEICE Transactions on Communications, vol. 94 pp. 3599-3602, 2011.

[8] N. Alsindi, B. Alavi, K. Pahlavan, "Spatial characteristics of UWB TOA based ranging in indoor multipath environments", in Proc. of 18th IEEE international symposium on personal, indoor and mobile radio communications, pp. 1-6, Athens, Greece, 2007.

[9] N.A. Alsindi, B. Alavi, K. Pahlavan, "Measurement and modeling of ultrawideband TOA-based ranging in indoor multipath environments", IEEE Transactions on Vehicular Technology, vol. 58, pp. 1046-1058, 2009.

[10] N. Reddy, B. Sujatha, "TDOA computation using multicarrier modulation for sensor networks", International Journal of Computer Science Communication Network, vol. 1, pp. 85-90, 2011.

[11] H. Obeidat et al., "Indoor localization using received signal strength", in Proc. of 8th IEEE Design and Test Symposium, 2013.

[12] M. Youssef, A. Agrawala, A.U. Shankar, "WLAN location determination via clustering and probability distributions", in Proc. of IEEE International Conference on Pervasive Computer Communications (PerCom), pp. 143-150, 2003.

[13] P. Bahl, V.N. Padmanabhan, "RADAR: an in-building RF-based user location and tracking system", in Proc of IEEE Infocom, pp. 775-784, Tel Aviv Israel, 2000. 